\title{
НОМЫН ШҮҮМЖ
}

\section{БНАСАУ судлалын шинэхэн бүтээлийн тухайд}

\author{
Дашнямын Золбоо \\ Доктор Ph.D, дэд профессор, ШУА-ийн Олон улсын харилцааны хүрээлэн, \\ Улаанбаатар, Монгол Улс \\ zolbood@mas.ac.mn
}

“Зүүн хойд Азийн аюулгүй байдал, стратеги судалгааны Монголын хүрээлэн” (ТББ)-гийн захирал, олон улс судлаач, докторант Нанжингийн Доржсүрэн "БНАСАУ-ын бие даасан эдийн засгийн хөгжлийн бодлого ба сорилтууд" (УБ., 2021) хэмээх нэгэн сэдэв бүтээлээ хэвлүүлжээ. Энэхүу бүтээл нь Монгол Улсад БНАСАУын эдийн засаг, хөгжлийн чиглэлийн асуудлаар дагнан гарсан анхны нэгэн сэдэвт бүтээл болж байна.

Тус хүрээлэнгийн Эрдмийн зөвлөлөөс шинэчлэн судалгааны тэргүүлэх баталсан чиглэлийн хүрээнд Солонгос судлалыг Солонгосын хойгийн хэмжээнд буюу БНСУ, БНАСАУ судлалыг ижил түвшинд авч үзэхийг зорилго болгосон юм. Тиймээс энэ чиглэлээр дагнан ажилладаг дотоод, гадаадын эрдэмтэн судлаачидтай идэвхтэй хамтран ажиллахыг эрмэлздэг бөгөөд энэХүY бүтээл хэвлэгдсэн явдалд туйлын талархан хүлээн авснаа тэмдэглэхийг хүсэж байна.

Нийт 173 тал хуудас бүхий уг бүтээл нь оршил, “БНАСАУ-ын бие даасан эдийн засгийн хөгжлийн бодлогын түҮх ба сорилтууд”, “XXI зуунд БНАСАУ-н эдийн засагт гарч буй өөрчлөлт ба сорилтууд”, “Хоёр Солонгосын эдийн засгийн харилцааны хүчин зүйлс", БНАСАУ-ын эдийн засгийн бодлого дахь хөрш орнууд БНХАУ, ОХУ, Монгол Улсын хүчин зүйлсийг тус бүрд нь авч үзсэн нийт зургаан бүлэг, 21 зүйл, нэгдсэн дүгнэлт, ном зүйн хэсгээс бүрджээ.

Оршил хэсэгт, БНАСАУ-ын бие даасан эдийн засгийн хөгжлийн суурь болох төвлөрсөн төлөвлөгөөт эдийн засгийн үзэл санааны үүсэл, хөгжил, эдийн засгийн системийн төрөл болон социалист төвлөрсөн төлөвлөгөөт эдийн засагтай байсан орнуудад хийгдсэн шинэчлэл өөрчлөлтийн үйл явц, БНАСАУ-ын хүн ам, байгалийн баялаг, эрчим хүч, зэвсэгт хүчний талаар мэдээллийг багтаажээ.

УГ бүтээлийн нэг, хоёрдугаар бүлэгт, БНАСАУ-ын бие даасан эдийн засгийн хөгжлийн түүхийг он дарааллаар нь 1948-2000 он болон 
XXI зууны эхэн үе хэмээн үечилж, тухайн хугацаан дахь төлөвлөгөөт эдийн засгийн бодлогуудтай нь холбон үзэх байдлаар ололт амжилт, сорилт бэрхшээлийг нь тодорхойлохыг оролджээ.

Харин гуравдугаар бүлэгт, хоёр Солонгосын эдийн засгийн харилцааны асуудлыг хөндсөн бол дөрөв, тавдугаар бүлгүүдэд хөрш орнуудаас нь тус улсын эдийн засагт эзлэх байр суурь, харилцаа, хамтын ажиллагаа ба цаашдын чиг хандлагыг тодорхойлохыг зорьжээ. Хилийн бүсийн аж үйлдвэрийн паркын үйл ажиллагаа нь хоёр Солонгосын харилцааг сайжруулахаас гадна "гуравдагч орны" хөрөнгө оруулалтыг татахад чиглэж байсан талаар дурджээ.

Тус улсын эдийн засагт хоёр хөрш ОХУ болон БНХАУ-ын гүйцэтгэж буй Үүргийг онцгойлон авч Үзсэн байна. Тухайлбал, тус улсын эдийн засгийн томоохон түншүүдийг нь 2005 оноос өнөөг хүртэлх хугацаанд гурав, гурван жилээр ангилан нарийвчилж гаргаснаар БНАСАУ-ын эдийн засагт БНХАУ-ын хүчин зүйл ямар чухал байр суурь эзэлдэг болохыг илтгэн харуулсан байна. Мөн ОХУтай хамтран хэрэгжүүлсэн болон төлөвлөсөн эдийн засгийн төслүүдийн үр дүн, өгөөжийн талаар дэлгэрэнгүй танилцуулжээ.

Бүтээлийн төгсгөлд Монгол Улс, БНАСАУ-ын эдийн засгийн харилцааны асуудлыг түүх ба орчин үе гэсэн хоёр хэсэгт хуваан авч үзсэн бөгөөд түүхэн харилцаа болон өнөөгийн нөхцөл байдалд тулгуурлан цаашид хоёр улсын эдийн засгийн харилцааг хөгжүүлэх боломж, гаргалгааны талаарх судлаачийн байр сууриа илэрхийлжээ.

Нэгэн сэдэвт бүтээл бүхэлдээ БНАСАУ-ын эдийн засгийн тогтолцоог гагцхүу бие даасан эдийн засгийн бодлого ба түүний хэрэгжилтийн үр дүн бус харин "хөгжлийн” (developing) бодлого хэмээх өргөн агуулгаар нэрлэж, түүнийгээ “өнөө цагт өрнөж буй үйл явц” болохыг нээн харуулахыг зорилго болгосон байна. Энэ хүрээнд БНАСАУ-ын бие даасан эдийн засгийн хөгжлийн бодлогыг түүхэн цаг үеийн нөхцөл байдалтай нь холбон өнөөгийн эдийн засгийн бодлогын онцлог, амжилт ололт ба сорилт бэрхшээл, цаашдын чиг хандлагыг тодорхойлохыг оролджээ. Чингэх Статистикийн Хороo (UNcomtrade - United Nations, Commodity Trade Statistics Database), БНСУ-ын Төв банк, Олон улсын худалдааны ассоциаци (KITA) зэрэг байгууллагын тайлан баримт, статистикаас голчлон эх сурвалж болгосон ажээ.

Судлаачаас, манай хоёр улс нийгэм, улс төрийн өөр байгуулалттай, хүрээлэн буй гадаад орчин болон эдийн засгийн хөгжлийн түүх нь харилцан адилгүй болохыг онцлоод суурь ойлголтын ийм их зөрүүтэй байдгийг нь манай зарим улс төрчид, нийгмийн нэр нөлөө бүхий томоохон зүтгэлтнүүд дэвэргэж, харьцуулан шүүмжилсээр байгаа нь тун оновчгүй бөгөөд залуу судлаачдыг “БНАСАУ судлал”-аас холдуулах нэг хүчин зүйл болсоор байгааг илчлэн шүүмжилсэнтэй бүрэн дүүрэн санаа нийлж байна.

Энэ мэтээр сонирхолтой үнэлэлт дүгнэлт бүхий энэхүу нэгэн сэдэвт бүтээл манай улсад тухайн сэдвээр гарч 
буй анхдагч бүтээл болохын хувьд ч, агуулга, үзэл санааныхаа хувьд ч тун чухал ач холбогдолтой ажил болсныг онцлон тэмдэглэж байна.

Гэвч үүний зэрэгцээ сайжруулах, засмаар зүйлс цөөн боловч харагдав. Тухайлбал, судлаач урьд өмнө манай эрдэмтдийн хийсэн судалгааны тухайд дурдаагүй ба Үүнийгээ манай улсад БНАСАУ-ын эдийн засгийн хөгжлийн түҮх, өнөөгийн байдал, цаашдын төлөвийн талаар хөндсөн эрдэм шинжилгээний бүтээл цөөн гарсан, гарсан нь ихэвчлэн БНАСАУ-ын асуудлыг хоёр Солонгосын харилцаа болон Солонгосын хойгийн асуудалд хамаатуулан судалж, үнэлэлт дүгнэлт өгсөн хэмээн тайлбарлажээ.

Гэтэл үнэн хэрэгтээ Монгол Улс дахь Солонгос судлал эртний уламжлалтай бөгөөд тус хүрээлэнгийн “Дорно дахин судлалын асуудал", “Өрнө-Дорно”, Зүүн хойт Ази судлал”, “Олон улс судлал”, Стратегийн судалгааны хүрээлэнгийн “Стратеги судлал” зэрэг эрдэм шинжилгээний сэтгүүлд Зүүн хойд Ази, Солонгосын хойгийн аюулгүй байдал, Солонгос орон судлалын асуудлыг хөндсөн 100 гаруй эрдэм шинжилгээний өгүүлэл, нийтлэл хэвлэгджээ. Эдгээрийн дотор Д.Начин "БНАСАУ-ын эдийн засгийн талаар" (ОУСС, 2010 оны №1-2, 115119-р тал), Д.Шүрхуу "БНАСАУын Ражин боомтыг олон улсын түвшинд ашиглах боломж, түүний ач холбогдол” (ОУСС, 2011, №3, 24$35-p$ тал) зэрэг холбогдох сэдвээр бичигдсэн өгүүллүҮд цөөнгүй байсныг харж болно. Мөн зохиогч бүтээлдээ анхдагч эх сурвалж цөөн ашигласан, нэг эх сурвалжаас олон удаа эшилсэн, солонгос хэлний бэрхшээл болон мэдээллийн хүртээмжийн асуудлаас шалтгаалан нэг талын мэдээллийг түлхүу хэрэглэсэн зэрэг зүйлс ажиглагдаж байгааг энд дурдах нь зүйтэй.

Түүнчлэн, хэдийгээр энэхүу нэгэн сэдэвт бүтээлийн агуулгатай шууд холбоогүй боловч Монгол Улс, БНАСАУ-ын асуудлыг хөндсөн бүлэгт хоёр талын харилцааг эдийн засгийн салбар тус бүрээр бүлэглэн авч үзсэн бол илүY үр өгөөжтэй, оновчтой байсан байх гэдгийг дурдмаар байна. Тухайлбал, Монгол Улсад хөдөлмөр эрхэлж байсан Солонгос иргэдийн мэдээллийг холбогдох төрийн байгууллагуудын статистик баримтад тулгуурлан гаргаж, шинжилгээ хийсэн бол илүү сонирхолтой байв.

Мөн Ном зүйн хэсгийг эх сурвалжийн хэлнээс гадна тус бүрд нь төрлөөр ангилсан бол илүҮ тодорхой, ойлгомжтой болох байжээ.

Эцэст нь тэмдэглэхэд, энэХУУ нэгэн сэдэвт бүтээл зохиогчоос тавьсан зорилгодоо бүрэн хүрсэн хэмээн үзэж болох бөгөөд манай улсын Солонгос судлал тэр дундаа БНАСАУ судлалд өөрийн хувь нэмрийг оруулж, баттай байр суурийг эзлэх нь гарцаагүй. Түүнчлэн манай улс төрчид, бодлого боловсруулагчид болон дипломатууд, эрдэмтэн судлаачид, их дээд сургуулийн багш, оюутнуудад чухал гарын авлага, судалгааны хэрэглэгдэхүүн болох нь тодорхой юм.

Олон улс судлаач Нанжингийн Доржсүрэнгийн цаашдын эрдэм судлалын ажил үйлсэд нь өндөр амжилт хүсэж, оюуны хур их, бүтээлийн ургац арвин байхыг ерөөе. 